\title{
Synovial fluid Waaler-Rose and latex tests
}

\author{
E. C. HUSKISSON, F. DUDLEY HART, AND B. W. LACEY \\ Westminster Hospital, London
}

Positive serum Waaler-Rose and Latex tests provide a useful confirmation of the clinical diagnosis of rheumatoid arthritis, but a significant number of patients remain persistently negative. Positive synovial fluid tests were reported in a few seronegative patients by Rodnan, Eisenbeis, and Creighton (1962), who suggested that this might be useful in diagnosis. We have reviewed all the WaalerRose and latex tests carried out on synovial fluid at this hospital in the last 6 years, with a view to assessing their value in diagnosis.

\section{Methods}

Waaler-Rose test on serum

All the saline used is 0.85 per cent. containing $\cdot 0001 \mathrm{M}$ $\mathrm{MgSO}_{4}$ and $\cdot 0001 \mathrm{M} \mathrm{CaCl}{ }_{2}$. Sheep cells are preserved in Alsever's solution, used when 4 to 7 days old and washed three or four times in saline. Anti-sheep red cell serum is prepared by inoculating rabbits intravenously at 4 to 5 day intervals with six to eight doses of $1 \mathrm{ml}$. 25 per cent. washed sheep cells suspended in saline. Serum is collected 7 days after the last injection and complement inactivated before use. Two-fifths of the minimal macroscopic agglutinating dose is used for sensitization. Sheep cells are sensitized by mixing $1 \mathrm{ml}$. packed thrice-washed cells suspended in $49 \mathrm{ml}$. saline with $50 \mathrm{ml}$. of suitably diluted rabbit anti-sheep cell serum. The mixture is incubated at $37^{\circ} \mathrm{C}$. for $30 \mathrm{~min}$., shaken every 5 to $10 \mathrm{~min}$.

Serum for test is inactivated at $56^{\circ} \mathrm{C}$. for $30 \mathrm{~min}$., absorbed at $37^{\circ} \mathrm{C}$. for $30 \mathrm{~min}$. with an equal volume of washed unsensitized sheep cells, and diluted two-fold serially in saline from 1 in 2 to 1 in 1024 . To $0 \cdot 2 \mathrm{ml}$. of the serum dilutions in Perspex trays (MRC pattern) is added $0.2 \mathrm{ml}$. sensitized red cells. Each tray, after shaking, is incubated separately at $37^{\circ} \mathrm{C}$. for $2 \mathrm{hrs}$. Results are read immediately, taking as end-point the dilution at which the sedimented cells form a pattern distinctly different from the perfectly circular solid 'buttons' in the controls.

\section{Latex test on serum}

The latex antigen is prepared from a 1 in 100 dilution of Polystyrene latex (BDH 30 per cent. suspension for rheumatoid arthritis fixation test') in $0.1 \mathrm{M}$ glycine in 0.85 per cent. $\mathrm{NaCl}$ at $\mathrm{pH} 8.2$. $10 \mathrm{ml}$. of the diluted latex suspension is poured into $20 \mathrm{ml}$. 0.25 per cent. human gammaglobulin (Fraction 2, Nutritional Biochemical Laboratories) and rapidly mixed. To the mixture is added $0.2 \mathrm{ml}$. 1 per cent. aqueous light green (GT Gurr) and $0.3 \mathrm{ml} .10$ per cent. sodium azide. The antigen is stored to stabilize at $5^{\circ} \mathrm{C}$. for not less than 48 hrs.

Serum for test is inactivated as for the Waaler-Rose test. A drop ( $0.05 \mathrm{ml}$.) of latex antigen is added to an equal volume of each serum dilution on Murray slides and the results are read after intermittent rocking for 3 min. at room temperature. Latex titres differing more than four-fold from Waaler-Rose titres are checked with those of Hyland Latex R.A. antigen. More than a twofold difference between the Westminster and Hyland antigens is exceptional.

\section{Tests on synovial fluids}

Synovial fluid is collected without anticoagulant. For both Waaler-Rose and latex tests, fluids of normal viscosity are treated exactly as serum. The occasional viscous fluid is treated with hyaluronidase before absorption with sheep red cells.

\section{Patients studied}

158 synovial fluids from 121 patients have been included in the series. In four patients sufficient information was not available to reach a diagnosis and they have been excluded. The patients were divided into two groups. Those in the former had definite or classical rheumatoid arthritis according to the criteria of the American Rheumatism Association (Ropes, Bennett, Cobb, Jacox, and Jessar, 1959). The remainder formed the nonrheumatoid group. There were 79 effusions from 56 patients in the rheumatoid group, and 79 effusions from 65 patients in the non-rheumatoid group. There was a predominance of females in the rheumatoid group $(2 \cdot 3: 1)$ and of males in the non-rheumatoid group $(1 \cdot 3: 1)$. Almost all the synovial fluid specimens were obtained from the knee joint. 


\section{Results}

(1) SERUM WAALER-ROSE AND LATEX TESTS The sensitivity of the tests carried out in a particular laboratory can be gauged from the results in a group of patients with rheumatoid arthritis. Fig. 1 shows serum Waaler-Rose and latex tests from 100 patients with rheumatoid arthritis selected randomly from those attending our clinic. They show a rather high incidence of sero-negative cases; 30 per cent. were sero-negative by the Waaler-Rose test (this corresponds closely with the 29 per cent. obtained when all patients attending the rheumatism clinic were last surveyed). 19 per cent. had negative latex tests, and in 13 per cent. both tests were negative.

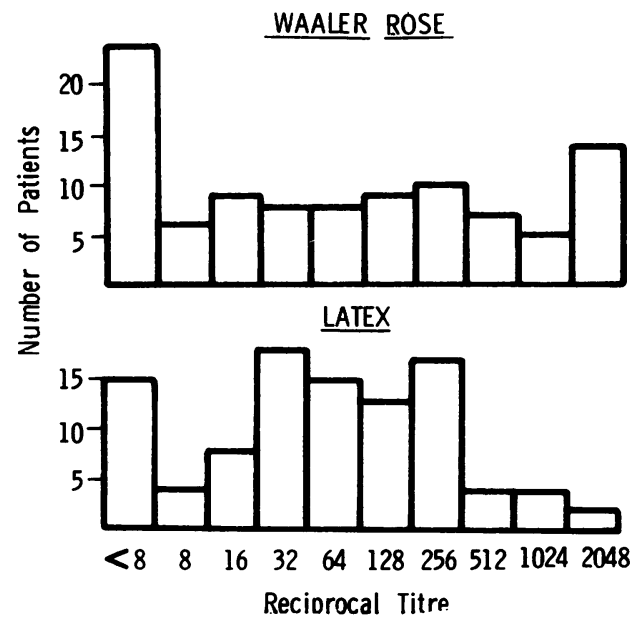

FIG. 1 Serum Waaler-Rose and latex tests on 100 patients with definite or classical rheumatoid arthritis selected randomly.

The serum Waaler-Rose and latex tests on the rheumatoid patients in the present series are shown in Fig. 2. The distribution suggests that these patients were reasonably representative of patients attending

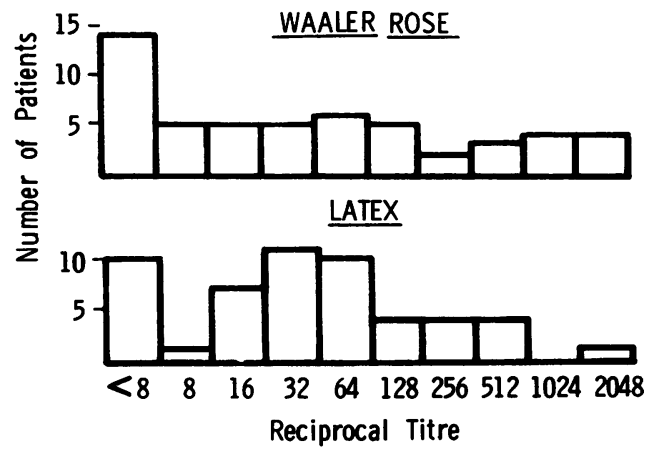

FIG. 2 Serum Waaler-Rose and latex tests on patients in the rheumatoid group. the clinic. In the non-rheumatoid group, one patient had a positive Waaler-Rose test and another had a positive latex test.

(2) SYNOVIAL FLUID WAALER-ROSE AND LATEX TESTS

The titres of synovial fluid Waaler-Rose and latex tests in the rheumatoid group are shown in Fig. 3. The distribution is similar to that of serum.

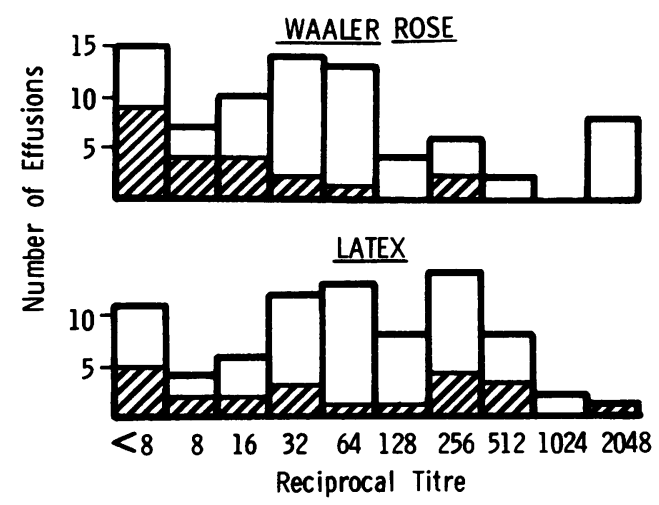

FIG. 3 Synovial fluid Waaler-Rose and latex tests on effusions from the rheumatoid group. Cross-hatched areas represent effusions from sero-negative patients.

Eight of the nineteen sero-negative patients (42 per cent.) had positive synovial fluid Waaler-Rose tests, all but two at a titre of 1 in 64 or less; twelve out of nineteen (63 per cent.) gave positive latex tests.

There was a fairly close relationship between serum and synovial fluid Waaler-Rose and latex tests as shown in Fig. 4 (opposite).

Synovial fluid titres from patients in the nonrheumatoid group are shown in Fig. 5 (opposite). A positive Waaler-Rose test was found in 24 patients (37 per cent.), and a positive latex test in seventeen (26 per cent.).

The diagnoses of the cases in the non-rheumatoid group are shown in Table I (opposite) divided into those with positive and those with negative synovial fluid Waaler-Rose tests. The age and sex distribution was similar. The mean age of the positive and negative groups was 50 and 45 years respectively; there were fourteen males and ten females in the positive group, and 24 males and eighteen females in the negative group. In the positive group, the twelve patients with osteoarthrosis were aged 39 to 73 years (mean 57). In nine the effusion was transient, often related to trauma, and resolved completely after 2 to 9 months. In three the arthrosis was chronic 


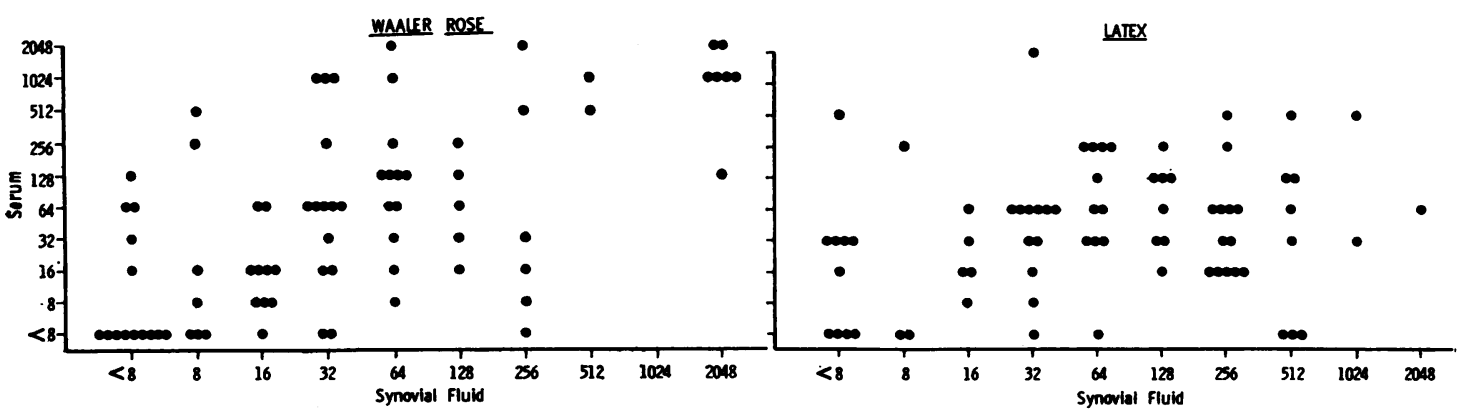

FIG. 4 Relationship of serum and synovial fluid. Waaler-Rose and latex tests in the rheumatoid group.

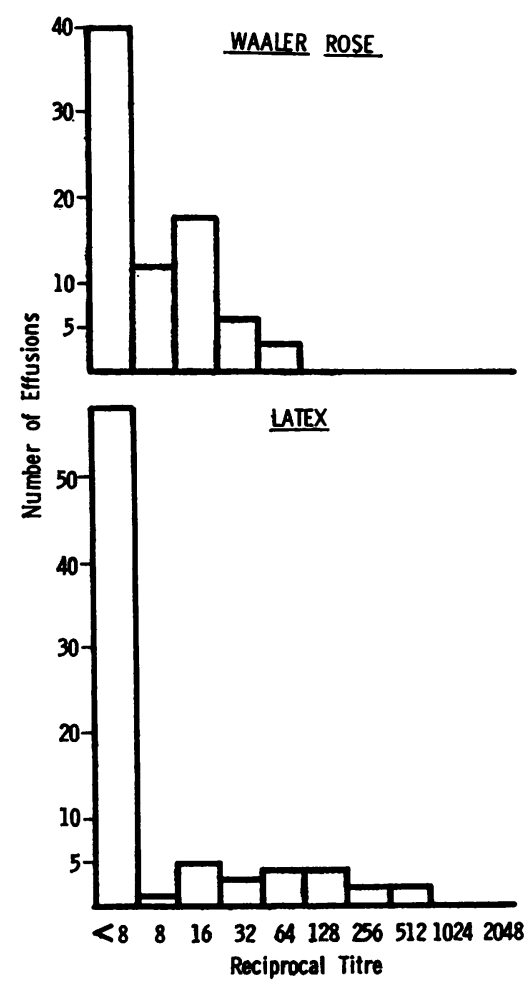

FIG. 5 Synovial fluid Waaler-Rose and latex tests on patients in the non-rheumatoid group.

one on the basis of an old fracture and one thought to be related to past Perthe's disease. Eight of the twelve patients had only one affected joint; in three both knees were affected and in one both knees and shoulders. $X$ rays showed degenerative changes in all cases. The erythrocyte sedimentation rate was available in six patients, five normal (6 to $14 \mathrm{~mm}$. in $1 \mathrm{hr}$ ), and one raised (in a patient who also had myelomatosis). Two patients aged 22 and 24 had a traumatic arthrosis with normal $X$ rays and went on to complete recovery. Two patients were classified as 'probable' and 'possible' cases of rheumatoid
Table I Diagnoses in 65 patients in the non-rheumatoid group, divided according to positive ( $>1$ in 16) or negative synovial fluid Waaler-Rose.

\begin{tabular}{|c|c|c|}
\hline Diagnosis & $\begin{array}{l}\text { Test results } \\
\text { Positive }\end{array}$ & Negative \\
\hline $\begin{array}{l}\text { Osteoarthrosis } \\
\text { Traumatic } \\
\text { 'Probable' RA } \\
\text { 'Possible' RA } \\
\text { Crohn's disease } \\
\text { Palindromic rheumatism } \\
\text { Gout } \\
\text { Reiter's disease } \\
\text { Sarcoidosis } \\
\text { Post-transplant arthritis } \\
\text { Psoriatic arthropathy } \\
\text { Acute arthritis (?septic) } \\
\text { Still's disease } \\
\text { Acute arthritis (various) } \\
\text { Ankylosing spondylitis } \\
\text { Polymyalgia rheumatica } \\
\text { Chronic tuberculous arthritis }\end{array}$ & $\begin{array}{r}12 \\
2 \\
1 \\
1 \\
1 \\
1 \\
1 \\
1 \\
1 \\
1^{*} \\
1 \\
1 \\
0 \\
0 \\
0 \\
0 \\
0\end{array}$ & $\begin{array}{l}6 \\
8 \\
0 \\
0 \\
0 \\
4 \\
2 \\
0 \\
0 \\
1^{*} \\
2 \\
0 \\
4 \\
11 \\
2 \\
1 \\
1\end{array}$ \\
\hline Total & 24 & 42 \\
\hline
\end{tabular}

- Positive on some occasions, negative on others.

arthritis in the absence of other diagnosis: one was a 51-year-old man with a persistent effusion of one knee which followed an acute arthritis in the same knee and both ankles, and the second was a 42-yearold man with a chronic effusion of one knee. There was one case of Reiter's disease, a 42-year-old man with acute arthritis of the knees accompanied by urethritis and conjunctivitis. He was the only seropositive patient in the group. There was one case of sarcoidosis, a 54-year-old woman with an acute arthritis of the knees and elbows accompanied by fever, lymphadenopathy, radiological enlargement of the hilar glands and pulmonary infiltration, and evidence of a gas transfer defect. The arthritis resolved completely. There were single cases of gout precipitated by thiazides, palindromic rheumatism, arthritis associated with Crohn's disease, psoriatic arthropathy, and arthritis following renal 
transplantation. An 11-year-old boy had an acute arthritis of one knee, from which inspissated pus was drained at exploration; this proved to be sterile but the arthritis resolved completely when he was treated with antibiotics.

The diagnoses were similar in the negative group. Eleven patients had an acute arthritis mostly during the course of another illness, for example postoperatively or as a complication of subacute bacterial endocarditis.

(3) PAIRED JOINTS AND REPEATED TESTS Eighteen patients had either more than one joint aspirated or joints aspirated on more than one occasion.

In three patients with rheumatoid arthritis, simultaneous specimens from the right and left knees were tested. All six were positive and the titres in each pair of knees did not differ by more than one dilution.

In fourteen patients, two to five aspirations were carried out. Eight had positive joint fluid WaalerRose tests and these remained positive on subsequent testing; one was initially positive and became negative. None became positive. The titres remained within one or two dilutions of the initial result except in one patient in whom the titre rose from 1 in 32 to 1 in 2,048 in 15 months. There was rather more variation in the results of the latex tests.

One patient had a number of examinations of both knees at different times (Table II). In this patient arthritis followed renal transplantation and full details have been reported elsewhere (Aichroth, Branfoot, Huskisson, and Loughridge, 1971). The results show that striking changes in titre can occur in a short time; there is a suggestion that the titres rose and fell during the course of the illness. Serum Waaler-Rose and latex tests were persistently negative.

Table II Reciprocal Waaler-Rose and latex titres in synovial fluids from a patient with arthritis following renal transplantation.

\begin{tabular}{|c|c|c|c|c|}
\hline \multirow[t]{3}{*}{ Date } & \multicolumn{4}{|l|}{ Knee } \\
\hline & \multicolumn{2}{|l|}{ Right } & \multicolumn{2}{|l|}{ Left } \\
\hline & Waaler-Rose & Latex & Waaler-Rose & Latex \\
\hline $\begin{array}{l}16.8 .67 \\
25.8 .67 \\
13.9 .67 \\
25.10 .67 \\
11.11 .67 \\
30.8 .68\end{array}$ & $\begin{array}{r}4 \\
8 \\
32 \\
16 \\
<4 \\
<4\end{array}$ & $\begin{array}{r}<2 \\
512 \\
32 \\
64 \\
32 \\
<2\end{array}$ & $\begin{array}{l}16 \\
\frac{16}{8} \\
<4 \\
<4\end{array}$ & $\begin{array}{l}<2 \\
\overline{1} \\
64 \\
<2\end{array}$ \\
\hline
\end{tabular}

\section{Discussion}

The results presented above suggest that synovial fluid Waaler-Rose tests are of little value in the diagnosis of rheumatoid arthritis. 42 per cent. of cases of sero-negative classical or definite rheumatoid arthritis were found to have positive synovial fluid Waaler-Rose tests compared with 37 per cent. in the non-rheumatoid group, and the distribution of titres in these two groups of patients was similar. Positive synovial fluid latex tests were commoner in the sero-negative rheumatoid group and less common in the non-rheumatoid group; the latex test may therefore be more useful.

It is possible that some cases of atypical rheumatoid arthritis have been included in the non-rheumatoid group, because the rheumatoid group was limited to patients with definite or classical rheumatoid arthritis according to the A.R.A. criteria. This division of cases was preferred because many different varieties of arthritis qualify as probable or possible rheumatoid arthritis; for example, a patient with bilateral osteoarthrosis causing persistent knee effusion. Palindromic rheumatism and Still's disease might also have been included in the rheumatoid group, but in these conditions the serum Waaler-Rose and latex tests are usually negative. In whatever way the cases were classified, a positive joint fluid Waaler-Rose test was at least half as common in the non-rheumatoid group as in patients with sero-negative rheumatoid arthritis.

The similar titres in the two groups and the high incidence (approximately one in three) of false positive results in patients with conditions such as osteoarthrosis, make the test a poor discriminator.

These results are in accord with previously published work. Rodnan and others (1963) found nine positive synovial fluid latex tests among nineteen patients with sero-negative rheumatoid arthritis or Still's disease. They noted three positive results in low titre in patients with diseases other than rheumatoid arthritis: one with degenerative joint disease and two with ankylosing spondylitis and peripheral joint involvement. Guariglia, Berkowitz, and Steinbrocker (1960) studied joint fluid latex tests in thirteen patients with diseases other than rheumatoid arthritis, and found two positive results, one in a patient with 'what appeared to be a traumatic effusion' and one in a case of lymphosarcoma involving the knee joint.

The unexpectedly high incidence of false positive results is also in accord with the work of Levine, Szanto, Grieble, Bach, and Anderson (1968) on pleural effusions; they found that 41 per cent. of fluids from patients with bacterial pneumonia and 20 per cent. of carcinomatous effusions gave positive latex tests.

The presence of rheumatoid factor produced locally in the synovial membrane has been thought to have pathogenic as well as diagnostic implications. Mellors, Heimer, Corcos, and Korngold (1959). demonstrated by fluorescent staining that rheuma- 
toid factor was present in the plasma cells of synovial membranes from patients with rheumatoid arthritis but not in normal subjects. Local synthesis of rheumatoid factor is likely to explain the high synovial fluid/serum ratio of rheumatoid factor found in some cases of rheumatoid arthritis (Hannestad and Mellbye, 1967). Our results suggest that rheumatoid factor can also be produced locally by non-rheumatoid synovial membranes and further study of such cases may prove interesting.

\section{Summary}

Synovial fluid Waaler-Rose and latex tests in patients with rheumatoid arthritis and with various other arthropathies have been reviewed. In sero-positive rheumatoid arthritis, the tests are usually positive and there is a fairly close relationship between titres in blood and synovial fluid. Some patients with sero-negative rheumatoid arthritis have positive joint fluid but the incidence of positive tests and the titres obtained do not differ markedly from those in patients with conditions other than rheumatoid arthritis.

We wish to thank Dr. R. I. S. Bayliss, Dr. D. A. Brewerton, Mr. David Evans, Prof. M. D. Milne, and Dr. R. D. Tonkin for permission to study patients under their care, Mrs. M. Maxwell and Miss A. Ramage for secretarial assistance, and the Medical Records Department and the Department of Medical Illustration.

\section{References}

Aichroth, P. M., Branfoot, A. C., Huskisson, E. C., AND Loughridge, L. W. (1971) J. Bone Jt Surg., in the press.

Guariglia, E., Berkowitz, S., AND Steinbrocker, O. (1960) Arthr. and Rheum., 3, 477 (Latex agglutination in serum and synovial fluid).

Hannestad, K., AND Mellbye, O. J. (1967) Clin. exp. Immunol., 2, 501 (Rheumatoid factor in synovial effusions: local production and consumption).

Levine, H., Szanto, M., Grieble, H. G., Bach, G. L., And Anderson, T. O. (1968) Ann. intern. Med., 69, 487 (Rheumatoid factor in nonrheumatoid pleural effusions).

Mellors, R. C., Heimer, R., Corcos, J., ANd Korngold, L. (1959) J. exp. Med., 110, 875 (Cellular origin of rheumatoid factor).

Rodnan, G. P., Eisenbeis, C. H., ANd Creighton, A. S. (1963) Amer. J. Med., 35, 182 (The occurrence of rheumatoid factor in synovial fluid).

Ropes, M. W., Bennett, G. A., Cobb, S., Jacox, R., ANd Jessar, R. A. (1959) Ann. rheum. Dis., 18, 49 (1958 revision of diagnostic criteria for rheumatoid arthritis).

\section{Appendix}

\section{Optimum discriminatory levels}

In ninety patients, 52 in the rheumatoid group and 38 in the non-rheumatoid group, all of whom had concurrent serum and synovial fluid WaalerRose and latex tests, a further analysis was made to determine the optimum levels of different tests and combinations of tests, which would give the best discrimination between the two groups, rheumatoid and non-rheumatoid. For any criterion, the number of patients who were correctly classified was calculated. Expressed as a percentage this provides an index of discrimination (D) of the test. For example, taking a serum Waaler-Rose titre of 1 in 16 as positive, 32 of the 52 patients in the rheumatoid group and 37 of the 38 patients in the non-rheumatoid group were correctly classified, giving an index of discrimination (D) of 77 per cent. 
Table III shows the optimum discriminatory levels using different combinations of the two tests. The following conclusions can be drawn:

(1) The normal criterion of Waaler-Rose positivity in serum (a titre of 1 in 16) was less discriminatory than a titre of 1 in 8 .

(2) In both serum and joint fluid the latex was more discriminatory than the Waaler-Rose test. In both serum and fluid the best criterion was 1 in 8 or above.

(3) Whatever the criterion the serum results were more discriminating than those of joint fluid.

(4) The diagnostic value of single tests fell in the following order:

(1) Serum latex (D : 87 per cent.)

(2) Serum WR (D : 82 per cent.) and joint latex (D : 82 per cent.)

(3) Joint WR (D : 70 per cent.)

(5) The best combination of two tests (D : 88 per cent.) was:

Serum latex 1 in 16 or Joint latex 1 in 8.

(6) The best combination of four tests (D : 90 per cent.) was:

Log sum (serum latex + serum WR) $=8$.

or Log sum (joint latex + joint WR) $=4$.

A titre of 1 in 4 was taken as $\log 1,1$ in $8 \log 2$, etc.

(7) The second best combination of four tests (D : 89 per cent.) was:

Serum latex 1 in 32 or serum WR 1 in 32. or Joint latex 1 in 32 or Joint WR 1 in 128.
Table III Effects of taking different criteria of positivity on the proportion of patients correctly classified as cases of rheumatoid arthritis or nonrheumatoid arthritis.

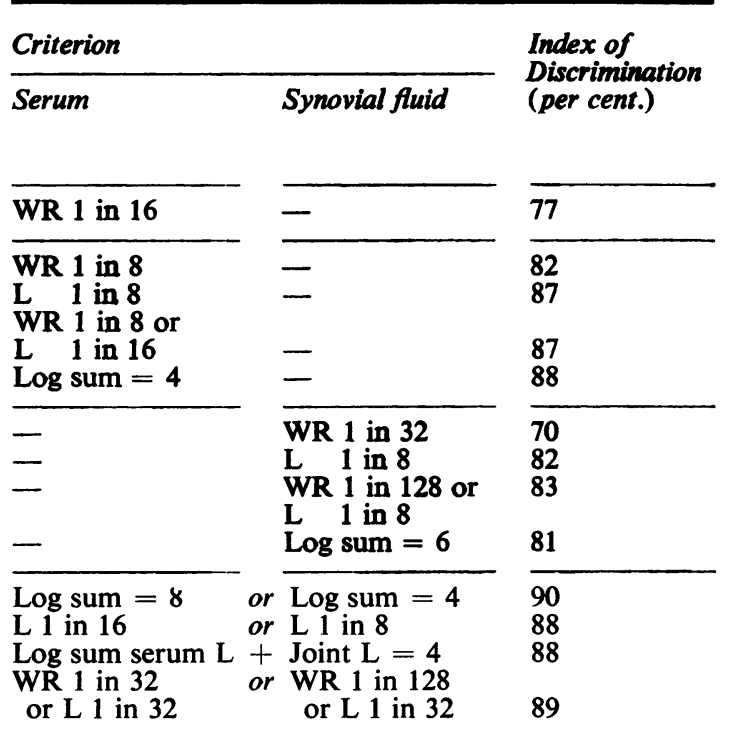

WR $=$ Waaler-Rose;

The sum of the results has been expressed on a log scale assuming that 1 in $4=1,1$ in $8=2,1$ in $16=3$, etc. The "index of discrimination' represents the number of patients correctly classified, expressed as a percentage. 
The results were expressed entirely on subjective findings; excellent was symptom-free, good had an occasional discomfort, fair had some symptoms but improved, and poor showed no improvement or became worse; 60.5 per cent. were rated as good or excellent and 10.4 per cent. as poor.

The indications for operation were intractable neck and arm pain, persisting in spite of adequate conservative treatment and due to degenerative or traumatic lesions of the cervical spine.

The authors emphasize the difficulty in selecting the disc or discs which were responsible for the symptoms. Of the methods of investigation available they found the disc distension test to be of the most value and used it routinely. After hyperextension injuries, a bulging disc, separation of a disc, or a rapidly collapsing disc point to the level at fault. Myelography was often misleading.

If the graft is not extruded (4 cases) or absorbed (26 cases), a solid fusion occurs in 10 to 12 weeks.

The best results were obtained in single or double level fusions. More extensive attempts were disappointing.

A. R. TAYLOR

Surgical Treatment of Stifiness of the Shoulder (Traitement chirurgical des raideurs de l'épaule) DARCY, M. (1970) Rev. Rhum., 37, 757

Metacarpophalangeal and Interphalangeal Joint Reconstruction: Use of Silicone Rubber-Dacron Prostheses for Replacement of Irreparable Joints of the Hand URBANIAK, J. R., MCCOLluM, D. E., and GOLDNER, J. L. (1970) Sth. med.J. (Bgham, Ala.), 63, 12817 figs, 13 refs

Experience of Synovectomy in Rheumatoid Arthritis (Erfahrungen mit Synovektomien bei rheumatoider Arthritis) MoHING, W. (1970) Med. Klin., 65, 2158 9 figs, 10 refs

Total Arthroplasty of the Hip (Bilan de l'arthroplastie totale de la hanche) Kerboull, M., Gardes, J.-C., Postel, M., and D'Aubigné, R. M. (1970) Presse méd., 78, 24574 figs, 13 refs

\section{Correction}

In the paper entitled 'Synovial Fluid Waaler-Rose and Latex Tests', by E. C. Huskisson, F. DudLey HaRT, and B. W. LACEY, which appeared in the January issue (Annals, 1971, 30, 67):

\section{Other general subjects}

Evidence for a Role of Proteimpolysaccharides in Regulation of Mineral Phase Separation in Calcfiying Cartilnge Pita, J. C., Cuervo, L. A., Madruga, J. E., Muller, F. J., and HowelL, D. S. (1970) J. clin. Invest., 49, 2188 4 figs, 21 refs

Community-Wide Streptococcal Control Project PhibBS, B., Taylor, J., and Zimmerman, R. A. (1970) J. Amer. med. Ass., 214, 20181 fig., 18 refs

Measurement of Rotation of the Spinal Column (Rotationsmessung der Wirbelsäule) PavelkA, K. (1970) $Z$. Rheumaforsch., 29, 3663 figs, 6 refs

The Intestine and Rheumatism OllhageN, B. (1970) Acta rheum. scand., 16, 17735 refs

Antistreptolysin and Antistaphylolysin Reactions in Rheumatoid Arthritis and Ankylosing Spondylitis (Antistreptolysin- und Antistaphylolysinreaktion bei chronischer Polyarthritis und Spondylitis ankylopoetica) SCHAEFER, J., and ZeIDLER, H. (1970) Med. Klin., 65, 1923 2 figs, 25 refs

Endophotography of the Knee Joint (Endofotografie des Kniegelenkes) GrösswaNG, F., and WRUHS, O. (1970) Endoscopy, 2, 1647 figs, 11 refs

Arthroscopy of the Knee: Technique, Indications, and Results (L'arthroscopie du genou: technique, indications, résultats) Tesson, M.-C., Aignan, M., and Delbarre, F. (1970) Presse méd., 78, 24676 figs, 10 refs

Arthroscopy of the Knee. Present Position (Arthroscopie du genou. Etat actuel de la question) DORFMANN, H., Dreyfus, P., Justin-Besançon, L., and Sèze, S. de (1970) Sem. Hôp. Paris, 46, 34429 figs 9 refs

Specific and Nonspecific Structures in Infiammatory Rheumatic Conditions (Spezifische und unspezifische Strukturen entzündlich-rheumatischer Erkrankungen) FAssbender, H. G. (1970) Med. Klin., 65, 215215 figs, 7 refs

On p. 69, col. I, Table 1, Legend please read 'positive $>$ 1 in 16 ,

A titre of 1 in 16 or greater was taken as positive throughout this study. 